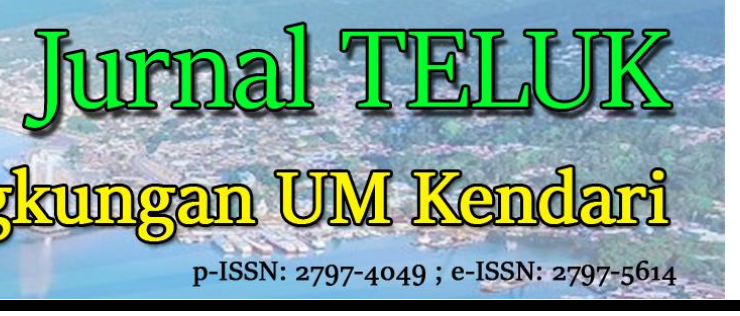

Artikel Penelitian

\title{
Perencanaan Instalasi Pengolahan Limbah Cair Rumah Sakit Aliyah 3 Kota Kendari
}

\author{
Suwardi ${ }^{a}$, Wa Ndibale ${ }^{a}$, M. Husni Kotta ${ }^{b}$, Ilham $^{c}$, Moch. Assiddieq ${ }^{a, *}$ \\ ${ }^{a}$ Program Studi Teknik Lingkungan, Fakultas Teknik, Universitas Muhammadiyah Kendari - Jl. K.H. Ahmad Dahlan No. 10, Kendari 93117 - Sulawesi \\ Tenggara, Indonesia. \\ ${ }^{b}$ Jurusan Teknik Arsitektur, Fakultas Teknik Universitas Halu Oleo - Jl.HEA Mokodompit Kampus Baru UHO, Kendari 93231 - Sulawesi Tenggara, \\ Indonesia. \\ ${ }^{c}$ Fakultas Teknik Universitas Halu Oleo - Jl.HEA Mokodompit Kampus Baru UHO, Kendari 93231 - Sulawesi Tenggara, Indonesia.
}

\section{INFORMASI ARTIKEL}

Sejarah Artikel:

Diterima Redaksi: 2 Mei 2021

Revisi Akhir: 23 Mei 2021

Diterbitkan Online: 1 Juni 2021

\section{KATA KUNCI \\ Discharge, Liquid Waste, Hospital}

\section{KORESPONDENSI}

Telepon:

E-mail: moch.assiddieq@gmail.com

\section{A $\quad$ B $\quad S \quad T \quad R A$ C $\mathbf{T}$}

\begin{abstract}
The purpose of this study was to determine the amount of liquid waste discharge at the hospital. Data from the number of hospital patient beds is 54 beds, so the activities taking place in Aliyah Hospital 3 in Kendari city produces a maximum discharge of liquid waste of 3.78/day. The form and design of processing liquid waste which is a rectangle with anaerobic- aerobic bio filter treatment system. Liquid waste processing with anaerobic-aerobic bio filter process consists of several parts namely the oil separator tank, equalization tank, early settling tank, anaerobic bio filter tank, aerobic bio filter tank, final settling tank and equipped with a chlorinated contractor tub. As for the size of each tank, which is like an oil separator tank $(0,9 \mathrm{~m} \times 0,5 \mathrm{~m} \times 0,7 \mathrm{~m})$, equalization tank $(2,6 \mathrm{~m} \times 1,3 \mathrm{~m} \times$ $1,1 \mathrm{~m})$, early settling tank $(1,6 \mathrm{~m} \times 0,8 \mathrm{~m} \times 0,9 \mathrm{~m})$, anaerobic bio filter tank $(2,5$ $\mathrm{m} \times 1,3 \mathrm{~m} \times 1,4 \mathrm{~m})$, aerobic bio filter tank $(1,8 \mathrm{~m} \times 1 \mathrm{~m} \times 1 \mathrm{~m})$, final settling $\operatorname{tank}(1,8 \mathrm{~m} \times 0,7 \mathrm{~m} \times 0,7 \mathrm{~m})$ and chlorinated tank $(0,6 \mathrm{~m} \times 0,3 \mathrm{~m} \times 0,4 \mathrm{~m})$. This process system was chosen because it is in accordance with the amount of liquid waste treatment system is safe, inexpensive and easy to operate.
\end{abstract}

\section{PENDAHULUAN}

Undang-undang Republik Indonesia Nomor 36 Tahun 2009 tentang Kesehatan bahwa kesehatan merupakan hak asasi manusia dan salah satu unsur kesejahteraan yang harus diwujudkan. Ketentuan tersebut menjadi dasar bagi pemerintah untuk memelihara dan meningkatkan derajat kesehatan masyarakat Indonesia dalam rangka pembentukan sumber daya manusia yang lebih baik dan peningkatan daya saing bangsa bagi pembangunan nasional. Dalam mencapai tujuan pembangunan di bidang kesehatan, rumah sakit merupakan bagian yang tidak terpisahkan dari sistem pelayanan kesehatan yang membutuhkan penanganan dan perhatian seksama (Dwi Ranta Sari, 2015).

Sesuai dengan Undang- Undang Republik Indonesia nomor 44 tahun 2009 tentang Rumah Sakit, pengertian rumah sakit adalah institusi pelayanan kesehatan yang menyelenggarakan pelayanan kesehatan perorangan secara paripurna yang menyediakan pelayanan rawat inap, rawat jalan dan gawat darurat. Rumah sakit merupakan institusi pelayanan bidang kesehatan dengan bidang preventif (pencegahan), kuratif (pengobatan), rehabilitatif maupun promotif. Jenis limbah yang ditimbulkan oleh kegiatan tersebut adalah limbah padat, cair, gas dan radioaktif yang dapat membahayakan bagi kesehatan dan lingkungan (Sri Subekti, 2005).

Berdasarkan UU RI No. 32 Tahun 2009 Tentang Perlindungan Dan Pengelolahan Lingkungan Hidup, suatu kegiatan diwajibkan untuk mengolah dan mengelola limbah hasil kegiatannya dalam rangka pelestarian fungsi lingkungan hidup dan limbah yang diolah dan dikelola tersebut wajib memenuhi standar baku mutu. Undang-undang ini dapat dijadikan dasar rumah sakit untuk mengelola limbah yang dihasilkan sampai memenuhi baku mutu lingkungan hidup. Rumah sakit perlu membangun instalasi pengolahan limbah cair yang mampu menghasilkan efluen yang aman untuk dibuang ke lingkungan dan memenuhi baku mutu. Rumah sakit aliyah 3 adalah salah satu infrastruktur kesehatan yang berada di tengah kota.

Rumah sakit aliyah 3 adalah rumah sakit milik swasta Kota Kendari yang berwujud RSU dan dinaungi PT. Nurul Aliyah Negeri. Segala kegiatan yang ada di dalamnya menimbulkan 
dampak positif dan negatif terhadap kehidupan sekitar. Dampak positifnya adalah meningkatnya derajat kesehatan masyarakat, sedangkan dampak negatifnya antara lain adalah sampah dan limbah medis yang dapat menimbulkan penyakit dan pencemaran lingkungan. Karena rumah sakit Aliyah berada di lingkungan padat penduduk, sehingga memiliki potensi besar sebagai sumber pencemaran penyakit di masyarakat.

Potensi dampak air limbah rumah sakit terhadap masyarakat sangat besar, maka berdasarkan keputusan Meteri Negara Lingkungan Hidup republik Indonesia nomor : Kep58/MENLH/12/1995 tentang baku mutu limbah cair bagi kegiatan rumah sakit, setiap rumah sakit diharuskan mengolah air limbahnya sampai memenuhi persyaratan standar yang berlaku. Selain itu rumah sakit Aliyah 3 belum memiliki sistem pengolahan limbah cair. Seiring dengan cepatnya pertumbuhan penduduk dan banyaknya pasien yang dirawat di rumah sakit akan berdampak pada meningkatnya jumlah limbah cair yang akan dihasilkan rumah sakit. Oleh sebab itu perlu direncanakan instalasi pengolahan limbah cair yang aman, murah serta mudah dalam operasionalnya.

\section{METODOLOGI}

\subsection{Tempat dan Waktu Penelitian}

Lokasi penelitian di Rumah Sakit Umum aliyah 3 Kota Kendari yang terletak di kelurahan Watubangga kecamatan Baruga kota Kendari Provinsi Sulawesi Tenggara, penelitian dilakukan selama satu bulan sejak November 2019 sampai dengan Desember 2019.

\subsection{Populasi dan Sampel}

Data kualitatif dalam penelitian ini adalah data yang diperoleh peneliti dari hasil observasi dan wawancara dengan pihak yang terkait. Data kuantitatif dalam penelitian ini adalah data yang berupa angka-angka dari hasil penelitian.

\subsection{Prosedur Kerja}

\subsubsection{Persiapan}

1. Melakukan survey di lokasi Rumah Sakit.

2. Pengumpulan data baik melalui buku, internet dan referensi- referensi lain.

3. Melakukan observasi, wawancara dan dokumentasi.

4. Menghitung jumlah limbah cair yang dihasilkan oleh Rumah Sakit Aliyah 3 Kota Kendari perharinya.

5. Mendesain perencanaan IPAL.

\subsubsection{Analisis Data}

Pengolahan data dilakukan setelah data - data yang dibutuhkan telah di kumpulkan. Adapun pengolahan data yang dilakukan meliputi:

1. Perhitungan debit air limbah serta karakteristik air limbah Rumah Sakit.

Adapun cara perhitungan debit rata-rata debit puncak sebagai berikut :

- Mengimput data debit pemakaian air selama satu tahun dalam tabel.

- Data debit yang berasal dari rekening pemakaian air diinput kedalam tabel. Adapun kolom yang di sediakan adalah bulan, pemakaian air, dan produksi air limbah.
- Menghitung produksi air limbah dari pemakaian air bersih.

Menurut Rosidi (2017), air limbah dihitung dengan cara mengasumsikan debit air limbah sebagai $70 \%$ pemakaian air.

- Perhitungan air limbah dilakukan dengan persamaan (1):

$$
Q_{\text {air limbah }}=70 \% \times Q_{\text {air bersih }}
$$

Keterangan : Qair limbah = debit air limbah $\left(\mathrm{m}^{3} /\right.$ detik $)$

Qair bersih $=$ debit air bersih $\left(\mathrm{m}^{3} /\right.$ detik $)$

- Menghitung debit air limbah rata-rata

Perhitungan debit air limbah rata-rata dilakukan dengan menjumlahkan seluruh produksi air limbah selama satu tahun kemudian membagi debit tersebut dengan jumlah bulan dalam satu tahun. Perhitungan debit rata-rata menggunakan persamaan (2):

$$
Q_{\text {ave }}=\frac{\sum Q}{12}
$$

Keterangan:

$\mathrm{Q}_{\text {ave }}=$ debit limbah rata-rata $\left(\mathrm{m}^{3} /\right.$ bulan $)$

$\sum \mathrm{Q}=$ jumlah debit dalam 12 bulan $\left(\mathrm{m}^{3} /\right.$ bulan $)$

Debit yang diperoleh selanjutnya dikonversi baik dalam satuan $\mathrm{m}^{3} /$ hari maupun dalan satuan $\mathrm{m}^{3} / \mathrm{jam}$. Cara mengkonversi debit disajikan persamaan (3) dan (4):

$$
\begin{aligned}
& Q_{\text {ave }}\left(m^{3} / \text { hari }\right)=\frac{Q\left(\frac{\mathrm{m} 3}{\text { bulan }}\right)}{30 \text { hari }} \\
& Q_{\text {ave }}\left(m^{3} / \text { hari }\right)=\frac{Q\left(\frac{m 3}{\text { hari }}\right)}{24 \text { jam }}
\end{aligned}
$$

- Menghitung debit peak

Debit peak dihitung dengan mengalihkan debit rata-rata dengan factor peak. Perhitungan debit peak menggunakan persamaan (5):

$$
Q_{\text {ave }}\left(m^{3} / \text { hari }\right)=Q_{\text {ave }} \times \text { faktor peak }
$$

Keterangan :

Qave = debit limbah rata-rata $\left(\mathrm{m}^{3} /\right.$ detik $)$

Faktor peak = pembagian debit puncak dengan debit limbah rata-rata.

Penetapan baku mutu effluent air limbah yang disesuaikan dengan peraturan Menteri Lingkungan Hidup dan Kehutanan Republik Indonesia Nomor P. 68/MENLHK/Sekjen/Kum.1/8/2016 baku mutu air limbah domestik.

Tabel 1. Baku Mutu Air Limbah

\begin{tabular}{lcc}
\hline Parameter & Satuan & Kadar maksimun* \\
\hline $\mathrm{pH}$ & - & $6-9$ \\
$\mathrm{BOD}$ & $\mathrm{mg} / \mathrm{L}$ & 30 \\
$\mathrm{COD}$ & $\mathrm{mg} / \mathrm{L}$ & 100 \\
TSS & $\mathrm{mg} / \mathrm{L}$ & 30 \\
Minyak dan lemak & $\mathrm{mg} / \mathrm{L}$ & 5 \\
Amoniak & $\mathrm{mg} / \mathrm{L}$ & 10 \\
Total Caliform & Jumlah/100 mL & 3000 \\
Debit & 1/orang/hari & 100 \\
\hline Sumber : PermenLHK No 68/Sekjen/Kum.1/8/2016
\end{tabular}


Baku mutu digunakan sebagai nilai pembanding untuk mengetahui apakah limbah yang telah diolah atau dihasilkan Rumah Sakit Aliyah 3 Kota Kendari sudah memenuhi syarat untuk dibuang ke badan air. Selain itu baku mutu dapat menjadi acuan dalam perancangan ini untuk mengetahui berapa nilai polutan yang dapat disisihkan agar dapat memenuhi baku mutu.

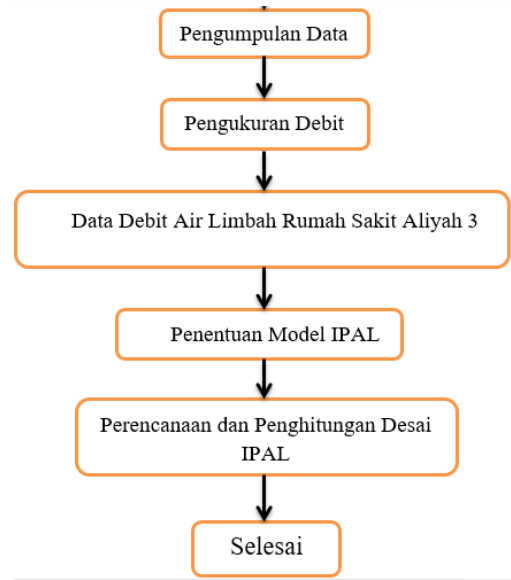

Gambar 1. Diagram alir penelitian

2. Perhitungan dimensi unit pengolahan yang telah ditetapkan berdasarkan kriteria desain

Perhitungan ditetapkan dilakukan berdasarkan pada kriteria desain yang telah ditetapkan sebelumnya berdasarkan literaratur. Adapun hal yang perlu dihitung dari setiap bangunan terkait dengan dimensi bak bangunan maupun saluran serta aspek hidrolika yang ada pada bangunan tersebut (kecepatan saluran, kecepatan dalam bangunan dan lain-lain).

Penggambaran DED (Detail Engineering Desain) masingmasing unit berdasarkan perhitungan menggunakan Auto CAD 2007. Gambaran detail merupakan tahap selanjutnya setelah dilakukan perhitungan dimensi unit pengolahan. Dalam gambar detail perlu digambarkan bentuk dari unit pengolahan secara jelas baik bentuk dan ukuran unit gambar. Gambar detail yang perlu dipersiapkan terdiri atas :

1) Layout tiap alternatif pengolahan

2) Denah tiap unit bangunan

3) Potongan tiap unit bangunan

\section{HASIL DAN PEMBAHASAN}

\subsection{Gambaran Umum Lokasi Penelitian}

Perencanaan ini menggunakan salah satu rumah sakit Aliyah 3 yang berlokasi di kota Kendari, yang terletak di Jalan Kristina Marta Tiahalu Kelurahan Baruga Kota Kendari, resmi beroperasi melakukan pelayanan kepada masyarakat (Gambar 2). Rumah Sakit Aliyah 3 merupakan rumah sakit yang dibangun Setelah Rumah Sakit Aliyah 1 dan RS Aliyah 2 berhasil mendapatkan perhatian dan tempat di mata masyarakat. Rumah Sakit Aliyah 3 diresmikan Kamis 3 Januari 2019 yang bertempat di Jalan Christina Tiahahu, Baruga, Kota Kendari oleh Pelaksanaan tugas Walikota Kendari Sulkarnain Kadir. Rumah sakit Aliyah 3 memiliki 54 tempat tidur yang terbagi atas ruang perawatan dewasa, ruang anak, ruang bersalin, dan ruang ICU.

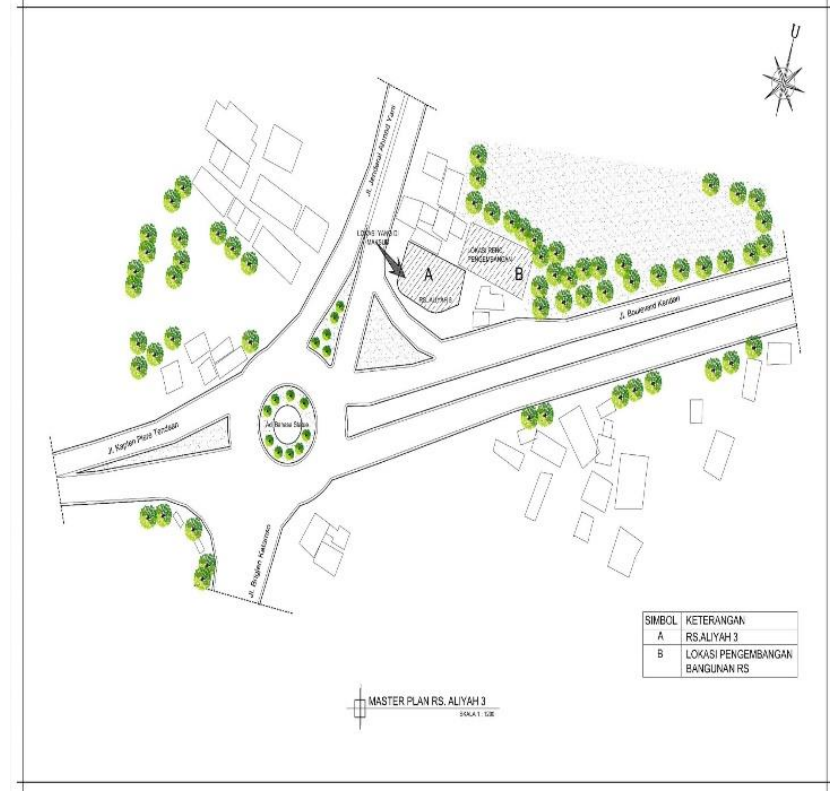

Gambar 2. Lokasi denah perencanaan IPAL RS. Aliyah 3

\subsection{Hasil Kajian IPAL}

\subsubsection{Perhitungan Perencanaan IPAL Rumah Sakit}

Potensi kecepatan aliran limbah cair didapatkan dengan cara mengasumsikan sesuai dengan jenis ruangan dan pengoperasiannya. Maka kecepatannya diasumsikan dan divariasikan antara 0,00005-0,001 m/s (Agus, dkk 2015).

Penentuan besarnya debit limbah cair diperlukan data berupa jumlah kebutuhan air bersih seluruh kegiatan yang berada di rumah sakit.

Tabel 2. Hasil Perhitungan Debit Limbah Cair Maksimum

\begin{tabular}{lc}
\hline \multicolumn{1}{c}{ Kebutuhan } & Nilai perhitungan \\
\hline $\begin{array}{l}\text { Kebutuhan Air bersih } \\
\text { (Q air bersih) }\end{array}$ & 27000 liter/hari \\
$\begin{array}{l}\text { Debit Limbah Cair } \\
\text { (Q limbah cair) }\end{array}$ & $0,00006 \mathrm{~m}^{3} / \mathrm{s}$ \\
Kapasitas Desain : & \\
$\quad$ Debit IPAL Maksimum & $5,4 \mathrm{~m}^{3} / \mathrm{hari}$ \\
COD Limbah Cair Maksimum & $500 \mathrm{mg} / \mathrm{L}$ \\
BOD Limbah Cair Maksimum & $300 \mathrm{mg} / \mathrm{L}$ \\
Konsentrasi SS & $300 \mathrm{mg} / \mathrm{L}$ \\
Total Efisiensi Pengolahan & $90 \%$ \\
COD Olahan & $80 \mathrm{mg} / \mathrm{L}$ \\
SS Olahan & $30 \mathrm{mg} / \mathrm{L}$ \\
\hline
\end{tabular}

Instalansi Pengolahan Air Limbah yang diperuntukan untuk mengolah air limbah yang dihasilkan dari rumah sakit Aliyah 3 kota kendari. Untuk membuat sebuah instalasi pengolahan air limbah di butuhkan proses perencanaan dengan beberapa tahapan - tahapan perhitungan data - data yang berupa angka yang telah berhasil dikumpulkan berdasarkan observasi lapangan, wawancara yang dilakukan terhadap pihak terkait, pengumpulan data dari pihak dan instansi terkait dan dari studi literatur yang telah dilakukan. Rumah sakit Aliyah 3 memiliki 54 tempat tidur yang terbagi atas ruang perawatan dewasa, ruang anak, ruang bersalin, dan ruang ICU.Untuk penggunaan air bersih per hari rata - rata 500 liter/bed.hari. 
Tabel 3. Standar Pemakaian Air Bersih Rata - Rata Sehari

\begin{tabular}{ccccc}
\hline Jenis gedung & $\begin{array}{c}\text { Pemakaian air } \\
\text { rata-rata sehari } \\
\text { (liter) }\end{array}$ & $\begin{array}{c}\text { Jangka waktu } \\
\text { pemakaian air } \\
\text { rata-rata sehari } \\
\text { (jam) }\end{array}$ & $\begin{array}{c}\text { Perbandingan } \\
\text { luas lantai } \\
\text { efekti/total (\%) }\end{array}$ & Keteragan \\
\hline $\begin{array}{c}\text { Perumahan } \\
\text { mewah }\end{array}$ & 250 & $8-10$ & $42-45$ & Setiap penghuni \\
\hline Rumah biasa & $160-250$ & $8-10$ & $50-53$ & Setiap penghuni \\
\hline Apartemen & $200-250$ & $8-10$ & $45-50$ & $\begin{array}{c}\text { Mewah 250 lt } \\
\text { Menengah 180 lt } \\
\text { Bujangan 120 lt }\end{array}$ \\
\hline Asrama & 120 & 8 & $45-48$ & bujangan \\
\hline Rumah Sakit & $\begin{array}{c}\text { Mewah>1000 } \\
\text { Menengah 500-1000 } \\
\text { Umum 350-500 }\end{array}$ & $8-10$ & & $\begin{array}{c}\text { Setiap tempat tidur pasien) } \\
\text { Pasien luar 8 lt } \\
\text { Staf/pegawai 120 lt } \\
\text { Keluarga160 lt }\end{array}$ \\
\hline
\end{tabular}

Sumber : Noerbambang dan Morimura, 2005

Jadi jumlah total penggunaan air bersih sebanyak 18.900 liter/hari, sedangkan jumlah air limbah yang timbul akibat dari pemakaian air ini yaitu sebanyak $20 \% \mathrm{X}$ debit air bersih menjadi air buangan. Jadi jumlah air limbah yang dihasilkan sebanyak 5.400 liter/hari. Setelah itu tahap selanjutnya dihitung dimensi dari unit - unit IPAL yang telah ditetapkan berdasarkan studi literatur yang terdiri dari bak pemisah minyak, bak ekualisasi , bak pengendap awal, bak biofilter anaerob, bak biofilter aerob, bak pengendap akhir dan bak khlorinasi.

\section{Perhitungan Dimensi Bak Pengolahan Limbah Cair}

Pada bak pemisah minyak ini air limbah yang akan masuk sebanyak 5.400 liter/hari dan lama dari waktu air tinggal di dalam bak selama $3.600 \mathrm{~s}$. volume dari bak ini sebesar $0,216 \mathrm{~m}^{3}$, dengan panjang $=0,9 \mathrm{~m}$, lebar $=0,5 \mathrm{~m}$ dan kedalaman $=0,7 \mathrm{~m}$.

Pada bak kedua yaitu bak ekualisasi bertujuan untuk mencapai debit konstan. Bak ini akan menampung air limbah dengan dengan jumlah yang sama yaitu 5.400 liter/hari dengan lama tinggal air limbah di dalam bak selama 43.200 s. Sedangkan volume dari bak ini sebesar $2,592 \mathrm{~m}^{3}$, dengan dimensi panjang 2,6 m, lebar 1,3 $\mathrm{m}$ dan kedalaman 1,1 $\mathrm{m}$.

Bak ketiga, yaitu bak sedimentasi/bak pengendapan awal berfungsi untuk menghilangkan zat padat yang tersuspensi.Bak ini akan menampung air limbah dengan dengan jumlah yang sama yaitu 5.400 liter/hari dengan lama tinggal air limbah didalam bak selama 14.400s. Sedangkan volume dari bak ini 0,864, dengan dimensi panjang 1,6 m, lebar 0,8 $\mathrm{m}$ dan kedalaman $0,9 \mathrm{~m}$.

Bak keempat yaitu bak biofilter anaerob berfungsi untuk menurunkan kandungan biological oxygen demand (BOD), chemical oxygen demand (COD) and total suspended solids (TSS) dari hasil olahan yang sesuai dengan baku mutu lingkungan hidup. Bak ini akan menampung air limbah dengan jumlah yang sama yaitu 5.400 liter/hari dengan lama tinggal air limbah didalam bak selama7 jam. Sedangkan volume dari bak ini 4,55 $\mathrm{m}^{3}$, panjang 2,5 m, lebar 1,3 m, dan kedalaman 1,4 m.

Bak kelima, yaitu bak biofilter aerob berfungsi untuk menurunkan kandungan biological oxygen demand (BOD), chemical oxygen demand (COD) dan total suspended solids (TSS) dari hasil olahan yang sesuai dengan baku mutu lingkungan hidup. Bak ini akan menampung air limbah dengan dengan jumlah yang sama yaitu 5.400 liter/hari dengan lama tinggal air limbah didalam bak selama 6 jam. Sedangkan volume dari bak ini $1,2 \mathrm{~m}^{3}$, panjang $1,2 \mathrm{~m}$, lebar $1 \mathrm{~m}$, dan kedalaman $1 \mathrm{~m}$.
Bak keenam, yaitu bak sedimentasi/bak pengendapan akhir berfungsi untuk menghilangkan zat padat yang tersuspensi. Bak ini akan menampung air limbah dengan jumlah yang sama yaitu 5.400 liter/hari dengan lama tinggal air limbah didalam bak selama $14.400 \mathrm{~s}$, Sedangkan volume dari bak ini $0,864 \mathrm{~m} 3$, panjang 1, $8 \mathrm{~m}$, lebar $0,7 \mathrm{~m}$, dan kedalaman $0,7 \mathrm{~m}$.

Bak ketujuh, yaitu bak khlorinasi. Bak ini akan menampung air limbah dengan dengan jumlah yang sama yaitu 5.400 liter/hari dengan lama tinggal air limbah didalam bak selama $900 \mathrm{~s}$, Sedangkan volume dari bak ini 0,054 m3, panjang 0,6 m, lebar $0,3 \mathrm{~m}$, dan kedalaman $0,4 \mathrm{~m}$.

Tabel 3. Perhitungan Dimensi Bak Pengolahan Limbah Cair

\begin{tabular}{lc}
\hline \multicolumn{1}{c}{ Kebutuhan } & Nilai perhitungan \\
\hline $\begin{array}{l}\text { Desain Bak Pemisah Lemak/ Minyak } \\
\text { (Q air bersin) }\end{array}$ & 27000 liter/hari \\
Debit Limbah Cair & $0,00006 \mathrm{~m}^{3} / \mathrm{s}$ \\
(Q limbah cair) & \\
Kapasitas Desain : & $5,4 \mathrm{~m}^{3} / \mathrm{hari}$ \\
Debit IPAL Maksimum & $500 \mathrm{mg} / \mathrm{L}$ \\
COD Limbah Cair Maksimum & $300 \mathrm{mg} / \mathrm{L}$ \\
BOD Limbah Cair Maksimum & $300 \mathrm{mg} / \mathrm{L}$ \\
Konsentrasi SS & $90 \%$ \\
Total Efisiensi Pengolahan & $80 \mathrm{mg} / \mathrm{L}$ \\
COD Olahan & $30 \mathrm{mg} / \mathrm{L}$ \\
SS Olahan &
\end{tabular}

\section{Perhitungan Desain Bak Pengolahan Limbah Cair}

Desain Bak Pemisah Lemak / Minyak

Data Perencanaan :

$\begin{array}{ll}\text { Q limbah cair } & =0,00006 \mathrm{~m}^{3} / \mathrm{s} \\ \text { Waktu Tinggal, WT } & =1 \mathrm{jam}(\text { Said d }\end{array}$

Waktu Tinggal, WT $\quad=1$ jam (Said dan Widayat, 2013) $=3.600 \mathrm{~s}$

Volume maksimum, Vmaks $=\mathrm{Q}$ limbah cair $\times \mathrm{WT}$ $=0,00006 \times 3.600$ $=0,216 \mathrm{~m}^{3}$

Kecepatan aliran, Vo $\quad=0,00005-0,001 \mathrm{~m} / \mathrm{s}$ Ruang bebas, $\mathrm{w}=30 \%$ dari tinggi Endapan, e $\quad=10 \%$ dari tinggi

Perhitungan dimensi bak :

$$
\begin{aligned}
\mathrm{P} & =\mathrm{V}_{\mathrm{o}} \times \mathrm{WT} \\
& =0,00025 \times 3.600 \\
& =0,9 \mathrm{~m} \\
\mathrm{~L} & =1 / 2 \times \mathrm{P}=1 / 2 \times 0,9=0,45 \mathrm{~m} \approx 0,5 \mathrm{~m}
\end{aligned}
$$




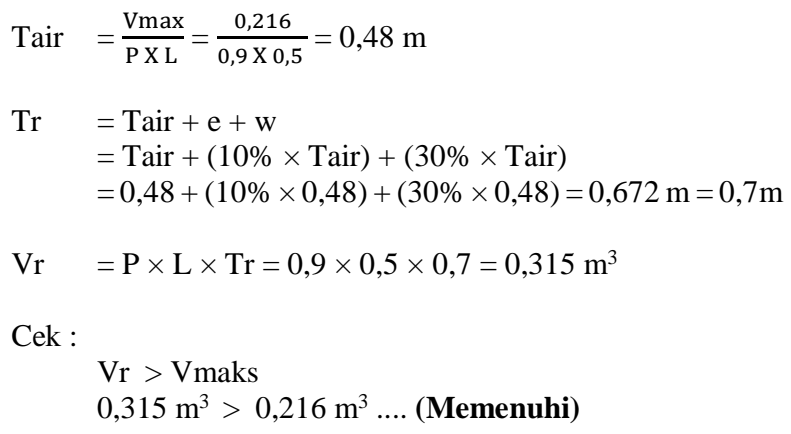

\section{Bak Ekualisasi}

Data Perencanaan :

Q limbah cair

Waktu Tinggal, WT

$=0,00006 \mathrm{~m}^{3} / \mathrm{s}$

$=12$ jam (Said dan Widayat, 2013)

$=43.200 \mathrm{~s}$

$=\mathrm{Q}$ limbah cair $\times \mathrm{WT}$

$=0,00006 \times 43.200=2,592 \mathrm{~m}^{3}$

$=0,00005-0,001 \mathrm{~m} / \mathrm{s}$

$=30 \%$ dari tinggi

$=10 \%$ dari tinggi

Ruang bebas, w

Endapan, e

Perhitungan dimensi bak :

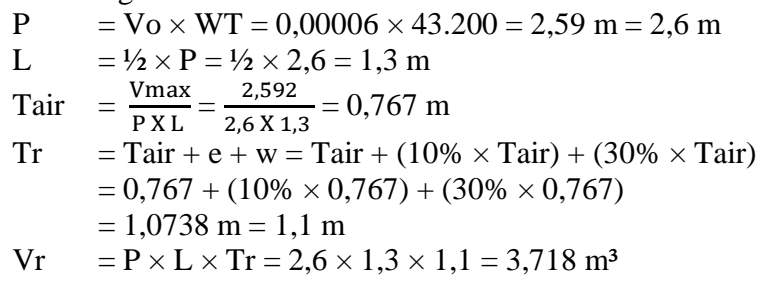

Cek :

$\mathrm{Vr}>\mathrm{Vmaks}$

$3,718 \mathrm{~m}^{3}>2,592 \mathrm{~m}^{3} \ldots$. (Memenuhi)

\section{Desain Bak Pengendapan Awal}

Data Perencanaan :

$\mathrm{Q}$ limbah cair $=0,00006 \mathrm{~m}^{3} / \mathrm{s}$

BOD masuk $\quad=300 \mathrm{mg} / \mathrm{L}=300 \mathrm{~g} / \mathrm{m}^{3}$

BOD keluar $\quad=225 \mathrm{mg} / \mathrm{L}=225 \mathrm{~g} / \mathrm{m}^{3}$

Efisiensi pengolahan $=\frac{(300-225)}{300} \times 100 \%=25 \%$

Waktu Tinggal, WT $=4$ jam (Said dan Widayat, 2013)

$$
=14.400 \mathrm{~s}
$$

Volume maksimum $=\mathrm{Q}$ limbah cair $\times \mathrm{WT}=0,00006 \times 14.400$

$$
=0,864 \mathrm{~m}^{3}
$$

Kecepatan aliran, Vo $\quad=0,00005-0,001 \mathrm{~m} / \mathrm{s}$

Ruang bebas, $\mathrm{w} \quad=30 \%$ dari tinggi

Endapan, $\mathrm{e} \quad=10 \%$ dari tinggi

Direncanakan dimensi bak :

$$
\begin{aligned}
\mathrm{P} & =\mathrm{Vo} \times \mathrm{WT}=0,00011 \times 14.400=1,58 \mathrm{~m}=1,6 \mathrm{~m} \\
\mathrm{~L} & =1 / 2 \times \mathrm{P}=1 / 2 \times 1,6 \mathrm{~m}=0,8 \mathrm{~m} \\
\text { Tair } & =\frac{\text { Vmax }}{\mathrm{P} \times \mathrm{L}}=\frac{0,864}{1,6 \times 0,8}=0,675 \mathrm{~m} \\
& =\text { Tair }+\mathrm{e}+\mathrm{W}=\text { Tair }+(10 \% \times \text { Tair })+(30 \% \times \text { Tair }) \\
\mathrm{Tr} & =0,675+(10 \% \times 0,675)+(30 \% \times 0,675)=0,945 \mathrm{~m} \\
& =0,9 \mathrm{~m} \\
\mathrm{Vr} \quad & \mathrm{P} \times \mathrm{L} \times \mathrm{Tr}=1,6 \times 0,8 \times 0,9=1,152 \mathrm{~m}^{3}
\end{aligned}
$$

Cek :

$\mathrm{Vr}>$ Vmaks

$1,152 \mathrm{~m}^{3}>0,864 \mathrm{~m}^{3} \ldots$. (Memenuhi)

\section{Desain Bak Biofilter Anaerob}

Data Perencanaan :

Q limbah cair $=5,4 \mathrm{~m}^{3} / \mathrm{hari}$

BOD masuk $\quad=225 \mathrm{mg} / \mathrm{L}=225 \mathrm{~g} / \mathrm{m}^{3}$

BOD keluar $\quad=75 \mathrm{mg} / \mathrm{L}=75 \mathrm{~g} / \mathrm{m}^{3}$

Efisiensi pengolahan : $\frac{(225-75)}{225} \times 100 \%=66,7 \%$

Kriteria perencanaan :

Pengolahan limbah cair dengan proses biofilter standar beban BOD per volume media adalah $0.4-4.7 \mathrm{~kg}$ BOD $/ \mathrm{m}^{3}$.hari. Untuk limbah cair rumah sakit ditetapkan beban BOD yang digunakan : $0.75 \mathrm{~kg} \mathrm{BOD} / \mathrm{m}^{3}$ media.hari

Beban BOD di dalam limbah cair

$$
\begin{aligned}
& =5,4 \mathrm{~m}^{3} / \text { hari } \times 225 \mathrm{~g} / \mathrm{m}^{3} \\
& =1215 \mathrm{~g} / \text { hari } \\
& =1,215 \mathrm{~kg} / \text { hari } \\
& =1,2 \mathrm{~kg} / \text { hari }
\end{aligned}
$$

Volume media yang diperlukan $\quad=\frac{1,2 \mathrm{~kg} / \mathrm{hari}}{0,75 \mathrm{~kg} / \mathrm{m}^{3} \cdot \mathrm{har}}=1,6 \mathrm{~m}^{3}$

Volume media $\quad=50 \%$ dari total volume reaktor

Volume reaktor yang diperlukan $\quad=2 \times 1,6 \mathrm{~m}^{3}=3,2 \mathrm{~m}^{3}$

Waktu tinggal di dalam Reaktor Anaerob $=\frac{1,6 \mathrm{~m}^{3}}{5 \mathrm{~m}^{3} / \text { hari }} \times 24$ jam $/$ hari $=7,68=7 \mathrm{jam}$

Waktu tinggal dalam reaktor Anaerob $=7$ jam, dengan kecepatan aliran dalam bak $=0,00005 \mathrm{~m} / \mathrm{s}$, sehingga dimensi Biofilter Anaerob menjadi :
Panjang
$=2,5 \mathrm{~m}$
Lebar
$=1,3 \mathrm{~m}$
Kedalaman air efektif $\quad=1 \mathrm{~m}$
Tinggi ruang bebas $\quad=0,3 \mathrm{~m}$
Tinggi ruang lumpur $\quad=0,1 \mathrm{~m}$
Volume reaktor rencana $=2,5 \times 1,3 \times 1,4=4,55 \mathrm{~m}^{3}$
Tinggi bed media pembiakan mikroba $=0,8 \mathrm{~m}$
Tinggi air di atas bed media $\quad=0,2 \mathrm{~m}$
Volume total media biofilter anaerob $=2,5 \times 1,3 \times 0,8=2,6 \mathrm{~m}^{3}$

Cek :

Volume Reaktor Rencana > Volume Reaktor Perlu $4,55 \mathrm{~m}^{3}>3,2 \mathrm{~m}^{3} \ldots$. (Memenuhi)

\section{Biofilter Aerob}

Data Perencanaan :

$\begin{array}{ll}\text { Debit Limbah } & =5,4 \mathrm{~m}^{3} / \mathrm{hari} \\ \text { BODmasuk } & =75 \mathrm{mg} / \mathrm{L}=75 \mathrm{~g} / \mathrm{m}^{3} \\ \text { BODkeluar } & =30 \mathrm{mg} / \mathrm{L}=30 \mathrm{~g} / \mathrm{m}^{3}\end{array}$

Efisien pengolahan $=\frac{(75-30)}{75} \times 100 \%=60 \%$

Beban BOD di dalam limbah cair $\quad=5,4 \mathrm{~m}^{3} /$ hari $\times 75 \mathrm{~g} / \mathrm{m}^{3}$

$$
=405 \mathrm{~g} / \mathrm{hari}
$$$$
=0,405 \mathrm{~kg} / \mathrm{hari}
$$$$
=0,4 \mathrm{~kg} / \mathrm{hari}
$$

$$
\begin{aligned}
\text { Jumlah BOD yang dihilangkan } & =60 \% \times 0,4 \mathrm{~kg} / \mathrm{hari} \\
& =0,24 \mathrm{~kg} / \mathrm{hari}
\end{aligned}
$$

Untuk pengolahan limbah cair dengan proses biofilter : Strandar Beban BOD per volume media 0,4 - 4,7 $\mathrm{kgBOD} / \mathrm{m}^{3}$.hari. Beban BOD yang digunakan $=0.75 \mathrm{kgB} \mathrm{BOD} / \mathrm{m}^{3}$.media.hari

$$
\begin{aligned}
& \text { Volume media yang diperlukan }=\frac{0,4 \mathrm{~kg} / \mathrm{hari}}{0,75 \mathrm{~kg} / \mathrm{m}^{3} \cdot \text { hari }}=0,5 \mathrm{~m}^{3} \\
& \text { Volume media } \\
& =40 \% \times \text { Volume Reaktor }
\end{aligned}
$$

Volume Reaktor Biofilter Aerob yang diperlukan

$$
=100 / 40 \times 0,5=1,25 \mathrm{~m}^{3}
$$


Waktu Tinggal di dalam Reaktor Aerob

$$
\begin{aligned}
& =\frac{1,25 \mathrm{~m}^{3}}{5 \mathrm{~m}^{3} / \mathrm{hari}} \times 24 \mathrm{jam} / \mathrm{hari} \\
& =6 \mathrm{jam}
\end{aligned}
$$

Reaktor dibagi menjadi dua ruang : ruang aerasi dan ruang biofilter, dimensi Ruang Aerasi Biofilter Aerob :

$\begin{array}{ll}\text { Panjang } & =0,6 \mathrm{~m} \\ \text { Lebar } & =1 \mathrm{~m} \\ \text { Kedalaman air efektif } & =0,6 \mathrm{~m} \\ \text { Tinggi ruang bebas } & =0,3 \mathrm{~m} \\ \text { Tinggi ruang lumpur } & =0,1 \mathrm{~m} \\ \text { Dimensi Ruang Biofilter } & \text { Aerob }: \\ \text { Panjang } & =1,2 \mathrm{~m} \\ \text { Lebar } & =1 \mathrm{~m} \\ \text { Kedalaman air efektif } & =0,6 \mathrm{~m} \\ \text { Tinggi ruang bebas } & =0,3 \mathrm{~m} \\ \text { Tinggi ruang lumpur } & =0,1 \mathrm{~m}\end{array}$

Waktu tinggal di dalam Reaktor Aerob $=\frac{1,8 \mathrm{~m} \times 1 \mathrm{~m} \times 1 \mathrm{~m}}{5 \mathrm{~m}^{3} / \text { hari }} \times 24$ jam $/$ hari $=8,64$ jam $=8$ jam

Waktu Tinggal di dalam Biofilter Aerob rata - rata $=8$ jam

Tinggi bed media pembiakan mikroba $\quad=0,5 \mathrm{~m}$

Tinggi air di atas bed media $\quad=0,2 \mathrm{~m}$

Volume total media pada biofilter aerob $=1,2 \mathrm{~m} \times 1 \mathrm{~m} \times 1 \mathrm{~m}$

Cek :

$$
=1,2 \mathrm{~m}^{3}
$$

BOD Loading per volume media $=\frac{0,4 \mathrm{~kg} / \mathrm{hari}}{0,6 \mathrm{~kg} / \mathrm{m}^{3}}$

$$
=0,7 \mathrm{~kg} \mathrm{BOD} / \mathrm{m}^{3} \cdot \text { hari }
$$

\section{Kebutuhan Oksigen}

Kebutuhan oksigen di dalam reaktor biofilter aerob sebanding dengan jumlah BOD yang dihilangkan,

Kebutuhan Oksigen Teoritis $=$ Jumlah BOD yang dihilangkan

Faktor keamanan $\pm 1,5$

$$
=0,315 \mathrm{~kg} / \mathrm{hari}
$$

Jadi, Kebutuhan Oksigen Teoritis $=1,5 \times 0,315=0,47 \mathrm{~kg} / \mathrm{hari}$

Temperatuh udara rata - rata $\quad=28{ }^{\circ} \mathrm{C}$

Berat Udara pada suhu $28^{\circ} \mathrm{C} \quad=1,1725 \mathrm{~kg} / \mathrm{m}^{3}$

Diasumsikan jumlah oksigen didalam udara 23,2 \%, jadi :

Jumlah Kebutuhan Oksigen Teoritis $=\frac{0,47 \frac{\mathrm{kg}}{\mathrm{hari}}}{1,1725 \frac{\mathrm{kg}}{\mathrm{m}^{3}} \times 0,232 \mathrm{~g} \frac{\mathrm{O}^{2}}{\mathrm{~g}} \text { Udara }}$

$$
=1,73 \mathrm{~m}^{3} / \text { hari }
$$

Efisiensi Difuser $=2,5 \%$ (gelembung kasar)

$$
\begin{aligned}
\text { Kebutuhan Udara Aktual } & =\frac{1,73 \mathrm{~m}^{3} / \text { hario }}{0,025}=69,20 \mathrm{~m}^{3} / \text { hari } \\
& =2,88 \mathrm{~m}^{3} / \mathrm{jam}=0,048 \mathrm{~m}^{3} / \text { menit }
\end{aligned}
$$

Blower Udara Yang Digunakan :

Spesifikasi Blower:

$\begin{array}{ll}\text { Tipe } & \text { : Hi Blow HP-60 } \\ \text { Merek } & : \text { Takatsuki } \\ \text { Kapasitas } & : 0,06 \mathrm{~m}^{3} / \text { menit } \\ \text { Jumlah } & : 2 \text { unit (operasi bergantian) }\end{array}$

\section{Diffuser :}

Kebutuhan Udara Aktual $=0,048 \mathrm{~m}^{3} /$ menit

Diffuser udara menggunakan diffuser tipe "Fine Bubble Diffuser" dengan spesifikasi sebagai berikut:
Size
: $250 \mathrm{~mm}$
Connectio Diameter : : $3 / 4-1$ “
Flow rate
: $60-80$ liter/menit
(tipikal = 70 liter/menit)
Material
: Plastic Single membrane

Jumlah Diffuser yang diperlukan $=\frac{48 \text { liter } / \text { menit }}{70 \text { liter } / \text { menit }}=0,69=1$ buah

\section{Media Pembiakan Mikroba}

Spesifikasi media biofilter yang digunakan:

$\begin{array}{ll}\text { Material } & : \text { PVC sheet } \\ \text { Ukuran Modul } & : 0,25 \mathrm{~m} \times 0,30 \mathrm{~m} \times 0,30 \mathrm{~m} \\ \text { Ketebalan } & : 0,15-0,23 \mathrm{~mm} \\ \text { Luas Kontak Spesifik } & : 200-226 \mathrm{~m}^{2} / \mathrm{m}^{3} \\ \text { Diameter lubang } & : 0,02 \mathrm{~m} \times 0,02 \mathrm{~m} \\ \text { Warna } & : \text { Hitam atau transparan } \\ \text { Berat Spesifik } & : 30-35 \mathrm{~kg} / \mathrm{m}^{3} \\ \text { Porositas Rongga } & : 0,98\end{array}$

Jadi, Jumlah Volume Total Media yang dibutuhkan :

Volume Total Media biofilter anaerob + Volume Total Media

\section{biofilter aerob}

Jumlah Volume Total Media yang dibutuhkan $=2,6 \mathrm{~m}^{3}+0,6 \mathrm{~m}^{3}$

$$
=3,2 \mathrm{~m}^{3}
$$

\section{Bak Pengendapan Akhir}

Data Perencanaan:

Q limbah cair

Waktu Tinggal, WT

$=0,00006 \mathrm{~m}^{3} / \mathrm{s}$

Volume maksimum

$=4 \mathrm{jam}=14.400 \mathrm{~s}$

$=\mathrm{Q}$ limbah cair $\times \mathrm{WT}$

$=0,00006 \times 14.400=0,864 \mathrm{~m}^{3}$

Kecepatan aliran, Vo

Ruang bebas, $w$

$=0,00005-0,001 \mathrm{~m}^{3} / \mathrm{s}$

Endapan, e

$\%$ dari tinggi

$=10 \%$ dari tinggi

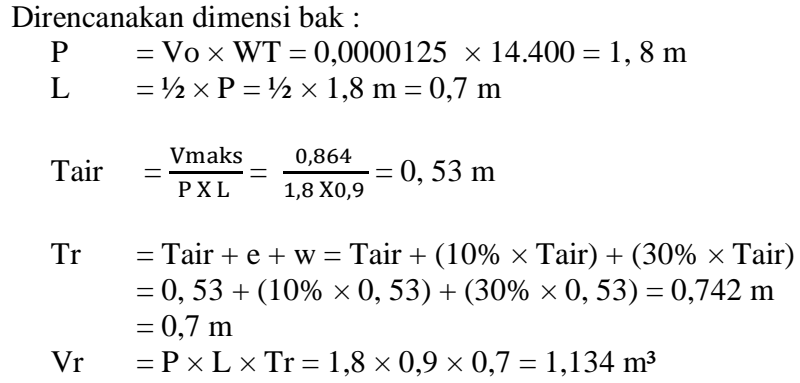

Cek :

$\mathrm{Vr}>\mathrm{Vmaks}$

$1,134 \mathrm{~m}^{3}>0,864 \mathrm{~m}^{3} \ldots$. (Memenuhi)

\section{Pompa Air Sirkulasi}

$\mathrm{Q}_{\text {limbah cair }}=5,4 \mathrm{~m}^{3} /$ hari

Spesifikasi pompa :

Tipe : Pompa celup/submersibel

Kapasitas $\quad: 0.1-0.02 \mathrm{~m}^{3} /$ menit

Bahan : Polimer atau Stainless steel

Total Head $\quad: 8-11.5 \mathrm{~m}$

Listrik $: 0.5 \mathrm{KW}, 220 \mathrm{~V}$

Diameter Outlet : 2 “

Jumlah : 2 unit (1 cadangan)

Desain Bak Khlorinasi

Data Perencanaan :
Q limbah cair
$=0,00006 \mathrm{~m}^{3} / \mathrm{s}$
Waktu Tinggal, WT
$=15$ menit $=900 \mathrm{~s}$
Volume maksimum
$=\mathrm{Q}$ limbah cair $\times \mathrm{WT}$
$=0,00006 \times 900=0,054 \mathrm{~m} 3$
Kecepatan aliran, Vo
$=0,00005-0,001 \mathrm{~m} / \mathrm{s}$
Ruang bebas, w
$=30 \%$ dari tinggi
Endapan, e
$=10 \%$ dari tinggi

Perhitungan dimensi bak :

$$
\mathrm{P}=\mathrm{Vo} \times \mathrm{WT}=0,00065 \times 900=0,59 \mathrm{~m} \approx 0,6 \mathrm{~m}
$$$$
\mathrm{L} \quad=1 / 2 \times \mathrm{P}=1 / 2 \times 0,6=0,3 \mathrm{~m}
$$ 


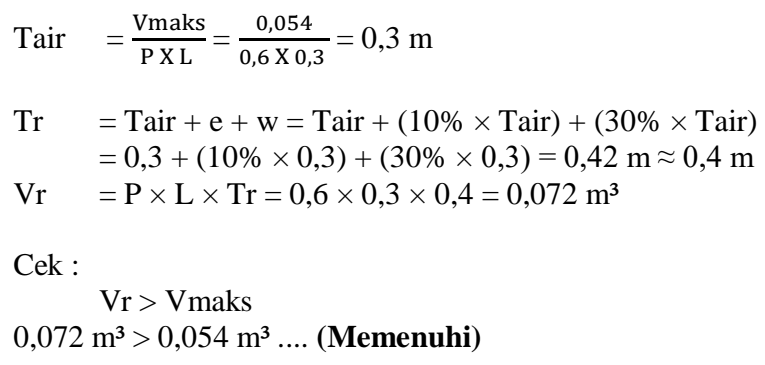

\section{KESIMPULAN}

Debit limbah cair maksimum sebesar 5,4 $\mathrm{m}^{3} /$ hari. Desain instalasi pengolahan limbah cair pada rumah sakit aliyah 3 kota Kendari yaitu dengan ukuran masing -masing bak yaitu bak pemisah minyak $(0,9 \mathrm{~m} \times 0,5 \mathrm{~m} \times 0,7 \mathrm{~m})$, bak ekualisasi $(2,6 \mathrm{~m} \times 1,3 \mathrm{~m} \times$ $1,1 \mathrm{~m})$, bak pengendap awal $(1,6 \mathrm{~m} \times 0,8 \mathrm{~m} \times 0,9 \mathrm{~m})$, bak biofilter anaerob $(2,5 \mathrm{~m} \times 1,3 \mathrm{~m} \times 1,4 \mathrm{~m})$, bak biofilter aerob $(1,8 \mathrm{~m} \times 1$ $\mathrm{m} \times 1 \mathrm{~m})$, bak pengendap akhir $(1,8 \mathrm{~m} \times 0,7 \mathrm{~m} \times 0,7 \mathrm{~m})$ dan bak khlorinasi $(0,6 \mathrm{~m} \times 0,3 \mathrm{~m} \times 0,4 \mathrm{~m})$.

\section{UCAPAN TERIMA KASIH}

Ucapan terima kasih kami sampaikan pada Program Studi Teknik Lingkungan atas pelaksanaan penelitian ini.

\section{DAFTAR PUSTAKA}

Departemen Kesehatan. (1995). Keputusan Menteri Kesehatan Republik Indonesia Nomor : 58/MENLH/12/1995 Tentang Baku Mutu Limbah Cair Rumah Sakit.

Dwi Ratna Sari 2015.Evaluasi Pengolahan Air Limbah dengan Sistem Extended Aeration di Runah Sakit "X" Semarang.Jurusan Ilmu Kesehatan Masyarakat Fakultas Ilmu Keolahragaan Universitas Negeri Semarang 2015.

Rosidi, 2017 .PerancanganInstalasiPengolahan Air Limbah (IPAL) PabrikKertasHalus PT.X Sidoarjo

Said, N.I., dan Widayat, W. (2013). Teknologi Pengolahan Air Limbah Rumah Sakit dengan Proses Biofilter AnaerobAerob. Pusat Teknologi Lingkungan Balai Pengkajian dan Penerapan Teknologi. Jakarta.

Sri Subekti 2005.Pengelolaan Air Bersih Rumah Sakit Sebagai Upaya Minimalis Limbah Cair. Program Paskasarjana Universitas Diponegoro Semarang 2005.

Undang-Undang Republik Indonesia Nomor 32 Tahun 2009 tentang Perlindungan dan Pengelolaan Lingkungan Hidup, Lembaran Negara Republik Indonesia Tahun 2009 Nomor 5063, Jakarta.

Undang-Undang Republik Indonesia Nomor 36 Tahun 2009 tentang Kesehatan, Lembaran Negara Republik Indonesia Tahun 2009 Nomor 5063, Jakarta.

Undang-Undang Republik Indonesia Nomor 44 Tahun 2009 tentang Rumah Sakit, Lembaran Negara Republik Indonesia Tahun 2009 Nomor 153, Tambahan Lembaran Negara Republik Indonesia Nomor 5072, Jakarta. 